\title{
Literary Anthropological in Lintang Lantip Novel by Aishworo Ang in Term of the Complexity of the Culture
}

\author{
Ardhian Nurhadi ${ }^{1}$, Herman J Waluyo ${ }^{2}$ and Slamet Subiyantoro ${ }^{3}$ \\ \{ardhiannurhadi@student.ac.id'1 , hermanjwaluyo@staff.uns.ac.id ${ }^{2}$, \& \\ s.biyantoro@staff.uns.ac.id ${ }^{3}$ \} \\ 1,2,3 Universitas Sebelas Maret, Surakarta, Indonesia
}

\begin{abstract}
This research aims to explain and describe some of the cultural aspects through the study of literary anthropology in Lintang Lanthip novel by Aishworo Ang. The Novel was chosen as the object of study because it contains many strong culture elements with setting on the coast of Gunungkidul, Yogyakarta. This research is qualitative, because of the data that used or analyzed from Lintang Lanthip by Aishworo Ang presence in quotes form. The approach method that used in this research is the literary anthropological approach. The reason why this theory is selected in the novel because of the research object in it described a strong background in the culture of local communities in the Gunungkidul Regency. The using main data is the quotes that delivered in resulting exposure form.. The results of this research show that the strong form of cultural elements such as (1) human life equipment, (2) livelihood, (3) social system, (4) language systems, (5) arts, (6) knowledge systems, and (7) religious systems. This elements as part of the complexity of the culture results which formed from communities system as the novel background.
\end{abstract}

Keywords: anthropology, culture, literature, novel, Lintang Lanthip

\section{INTRODUCTION}

The novel is considered as one of the media that able to provide a place for the existence of the culture in the communities system. Through its telling, the novel describes character's life with real descriptions in certain communities system. In line with what Sayuti said who tells that novel also allows the presence of very long presentation about a certain place (space) [1]. Furthermore, fiction prose comes from the word orate provosa too which means telling techniques are unraveled, directed and not compacted [2]. The novel is also able to expose some of the chain of events that coherent and review in detail especially on the dominant elements of the culture. The novel presented a much more realistic picture of social life [3]. In his opinion, literary works with verbal symbols have some roles in it such as model of comprehension, mode of communication, and mode of creation [4].

On the research tells that novels as a reflection of the real society cannot avoid describing thoughts, feelings, reactions and the image of each character [5]. Added on the research, literature contains an ethical and moral value relating to daily life including human problems [6]. On base, this concept presents the novel as a medium of communication and inter- 
communities interactions which depicted on a deep understanding of the story. The research that done on the old culture, probe the aspects of local wisdom in a certain culture. Then the analysis results of the local wisdom in Lawas used as a reference in the development of the curriculum at all levels of formal education [7]. While on the other research, purposefully formed spiritual and moral culture determines the behavior of the person in the family, the society, the world, belonging to a social community and acts as a basis of dialogue, communication and cooperation, both between people and between social communities and civilizations [8]. Both refer to cultural elements as a tool for finding the value aspects in it. The research on the literary work that has ever done is Racial Discrimination In Tjaraka's Sripanggung: Derrida Deconstruction Analysis focused on the research aspects of the deconstruction theory with some data like excerpts of racial attitudes in the novel [9]. Furthermore, the other literary works research Ririn directed research on the value of hard works from the character Marni in Entrok novel by Okky Madasari [10].

Lintang Lanthip novel was chosen as an object because it is one of the literary works that contain strong cultural elements [11]. The research with this novel as an object has not been done on previous research. This novel has also been filmed under the title Mars in May 2015 which coincide with the National Education Day. The film has been widely used as a motivation tool for students, especially in the Gunungkidul Regency.

\section{METHOD}

This research is a qualitative descriptive study type. Qualitative research is a research that intends to understand the phenomenon of what is experienced by the subject, such as behavior, perceptions, motivations, actions, and others as holistically way, and by the description in the form of words and language, in a special natural context and by utilizing various scientific methods [12]. The approach method that used in this study is the literary anthropology. The main data source in this research is the text in Lintang Lanthip novel by Aishworo Ang work. The data analysis techniques use a content analysis method which focused on the contents of the novel as an object of research.

\section{RESULT AND DISCUSSION}

Literary anthropology is the research of reciprocal influence between literature and culture [13]. According to Koentjaraningrat elements of culture are distinguished into seven types: (1) the equipment of human lives (2) livelihood, (3) societal system, (4) language system, (5) the art, (6) knowledge system, and (7) religious system [14].

\subsection{The Equipment of Human Life}

Results of the oldest culture in human life are home, clothes, and many types of equipment needed in everyday life. In research of Arswendo Atmowiloto's Canting novel there was a shift in Javanese culture in terms of equipment. Equipment emphasized in the form of shifting knowledge from traditional to modern [15]. While in this novel, even though it is modern, it still uses traditional equipment. The following are aspects of the human life equipment in the novel. The aspects of human life equipment based on the novel are following below:

"Dia berdiri di bawah pohon Dadap yang dulu banyak didatangi anak-anak yang ingin membuat sawangan" (halaman 147) 
He was standing under a dadap tree that had been visited by many children who wanted to make peace. (page 147)

The quotes above show a certain tool such as sawangan which created and affixed to the bird. So when the bird flew the sawangan will be making noise. The tools are commonly used as toys by children in the village. The other quote shows the usage of pelinteng or commonly called as slingshot. It creates from timber, rubber, and stone as a bullet. This slingshot tool is commonly used for hunting animals such as birds, locusts, or crickets.

\subsection{Livelihoods}

Livelihood is the main problem in life because of the continuity of life occurs solely with fulfilled various forms of physical needs. In research conducted on Maduranese culture, men acted as field hijackers with domestic cows, while the women were planting corn in the fields [16]. In this novel, the existence of rural communities which generalized on traditional matters capable of herding into a specific culture of livelihood. The analysis result of livelihood in novel Lintang Lanthip is following by:

"Mereka baru akan kembali ke dusun ketika hujan datang. Mereka akan mengerjakan tanahtanah atau beternak kambing-kambing ..." (halaman 24)

"They will just return to the hamlet when the rain comes. They will work on the lands or raise the goats... "(page 24)

Quotes above show the work as farmers described directly with the equipment that they used. As semiotics, that depiction refers to the livelihood of farmers, because this thing is identical with the bamboo basket which contains grasses for forage. The other quotes show another livelihood of villagers beside works on rice fields but also raising goats. In addition as farmers, the villagers usually work as a breeder.

\subsection{Societal System}

Society and culture are so difficult to be separated. The difference between both of them can be recognized through the viewpoints, intensity, and other ways that are done when the process of understanding happen. In other studies, community systems have problems with identity. Identity is a series of behaviors, emotions, and mindsets that are unique to each individual who defines them as members of a particular group. While in this study, the social aspect is more directed towards mutual cooperation and togetherness [17]. The study of the analysis result from of societal system in Lintang Lanthip novel is following below:

"Seperti sebagai penduduk pesisir lainnya jika malam berlangit cerah dan banyak bintang, penduduk Manggarsari akan keluar rumah dan berkumpul di salah satu halaman rumah yang dirasa paling strategis..." (halaman 18)

"Like most other coastal residents if the sunny night and many stars, Manggarsari residents will go out and gather on one of the yard which is most strategic ..." (Page 18)

The excerpt shows that the culture of society still strong in the bonds of hospitality and family. How they got together just to enjoy the atmosphere of nature in the countryside. Even the activities like that still often done today until evening. The other quote describes generally pictures of Rasulan as a culture that already has taken place through generations since the first time. The function is as a prayer or Thanksgiving to God Almighty for all of the gifts that $\mathrm{He}$ 
has given. This Rasulan tradition is usually carried out in the summer after harvest. To express that gratitude, then the community making food or doing a banquet at his home as a charity form to others fellow man.

\subsection{Language System}

The language system is the use of aspects of regional language or the absorption language used in the story. In research carried out on the novel by Gabriel Garcia Marquez, aspects of language and literature acted as effective means to describe the historically critical aspects of Latin America. Themes taken were such as solitude, labyrinth, slaughter, death, male domination, abduction and superstition among many others [18]. Research on Sengkuni Political Style and Semar Aesthetic, shows that politics, culture, and literature have a connection that results in two metaphorical political styles [19]. While in this novel, linguistic aspects of metaphor are more prominent in the dialect of local communities. The following are the results of language analysis in the novel which then forms a new slang in the community system.

"Ketika ada penduduk yang duwe gawe..." (halaman 8)

"When there are people who have celebration ..." (page 8)

“...akan datang ke dusun-dusun membawa membawa rokok bermacam-macam merek, wedhang gendheng. " (halaman 232)

"... will come to hamlets carrying cigarettes with various brands, wedhang gendheng." (Page 232)

The phrase duwe gawe refers to an activity or event that is usually held in a village by a family. Usually, the event is a celebration or Thanksgiving to commemorate something. The connotative term described in the wedang gendheng phrase has the meaning of a drink that can make crazy. This does not mean crazy in real interpretation, but crazy which means getting drunk. The term is a subtle language used in referring to liquor.

\subsection{Art System}

The aspect of art refers to the value of beauty (aesthetics) which comes from the expression of human desire for beauty that is enjoyed with the eyes or ears. In research in the novel Batas by Akmal Nasery Basral, it is mentioned in Dayak ethnic arts that it has aspects of sound art and traditional musical instruments. Some of these Dayak cultures have been lost, but some have experienced a shift in values and meanings because they are no longer relevant to the present condition of society [20]. While in the novel, some songs have been lost or unknown. The following is an analysis of the aspects of arts in the Lintang Lanthip novel.

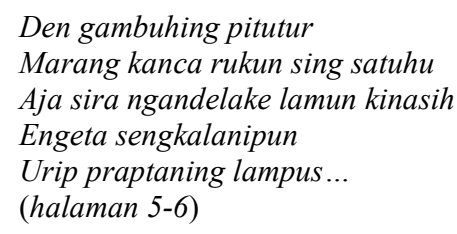

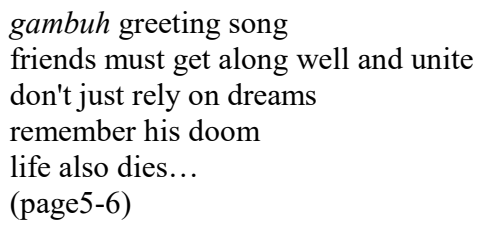

The excerpt of the song illustrates that children in that regional always sing songs cheerfully while chatting. The song contains advice and virtues that humans must do while living side by side with other humans in the world. 


\subsection{Knowledge System}

This knowledge system can be analyzed, including based on nature, plants, the human body, human behavior, and time-space. In a research entitled Oh Lebanon, explaining that the trauma of war motivated the sex of Arabian women to react to male domination and tradition because of war. Knowledge in this case breaks down the existing gender boundaries between men and women [21]. Other research, The Season of Migration to The North revealed that the main character, Saeed was not a nationalist. Instead, he is a hybrid cultural character who both identifies with British western culture and Sudanese oriental culture. Knowledge in this aspect is related to thinking [22]. Meanwhile, in the Lintang Lanthip novel, knowledge is interpreted in technological change. Here are some aspects of the knowledge system obtained from the Lintang Lanthip novel.

"Bila senja turun saat langit cerah, Ibu selalu mengajakku keluar rumah, menunjukiku bintang berwana merah yang berkelip-kelip indah. Itu planet Mars ... ” (halaman 3)

"When dusk falls when the sky is clear, Mother always takes me out of the house, points to me with a beautiful twinkling red star. That planet Mars... "(Page 3)

The quote above shows that people in the village have known the existence of the brightest stars in the sky which are called Lintang Lanthip or Mars. The other quote, knowledge shows that looking for leaves to be sold became Palupi's habit since middle school. The leaves are usually sold and made as packs of meat or rice that sold in traditional markets by the buyer.

\subsection{Religious System}

According to Koentjaraningrat, religion is a system consisting of four components, namely (a) religious emotion, (b) belief system, (c) ritual system, and (d) ceremony of the people or social unity. In another study, the cultural element of Nyoman Manda's Togog short story was presented through customs as another cultural element. Then semiotics, the short story "Togog" as a sign is an index for the socio-cultural situation in Balinese society that is interacting with the life of the tourism world [23]. Meanwhile, in the Lintang Lanthip novel, the religious aspect is related to people's belief in the existence of Allah. Here are some aspects of the religious system based on the Lintang Lanthip novel.

“Palupi menutup ceramahnya dengan mengutip sebuah ayat dalam Al-Quran..." (halaman 307)

"Palupi closed her speech by citing a verse from Al-Quran..." (page 307)

The first quotation shows a character was one of the residents who embraced Islam, nevertheless he continued to follow various regional traditional ceremonies as part of gratitude and establish hospitality between the villagers. The second quote gives an idea of the religious and smarter figure of Palupi as she grew older and her studies when she was asked to fill a seminar on astronomy. His struggle as a child also experienced a turning point [24][25].

\section{CONCLUSION}

The study of literary anthropology in Aishworo Ang's Lintang Lanthip novel looks at the seven aspects of anthropological studies according to Koentjaraningrat, where culture is divided into seven elements, namely (1) human life equipment, (2) livelihood, (3) social 
system, (4) language systems, (5) arts, (6) knowledge systems, and (7) religious systems. The whole aspect is found in the Lintang Lanthip novel. Besides that, even though it has two backgrounds, but the development in the story is able to direct the reader to navigate the ins and outs of the culture in Gunungkidul Regency. It was also explained that the local community still has a strong traditional culture, although it is undeniable that all modern things have entered the area. Based on the study of literary anthropology, Aishworo Ang's novel Lintang Lanthip contains all aspects that are the subject of research studies.

\section{REFERENCE}

[1] Suminto A. Sayuti., Berkenalan dengan prosa fiksi. Yogyakarta: Gama Media, 2000.

[2] H. J. Waluyo, Pengkajian dan Apresiasi Puisi. Yogyakarta: Penerbit Ombak, 2010.

[3] H. T. Faruk, Pengantar Sosiologi Sastra. Yogyakarta: Pustaka Pelajar, 1994.

[4] Kuntowijoyo, Budaya dan Masyarakat (Edisi Paripurna). Yogyakarta: Tiara Wacana Yogya, 2006.

[5] K. Y. Hun and U. H. A. Hassan, "Dakwah, Wealth and Desire of Sexuality in Islam: the Concept of Love in Habiburrahman El-Shirazy'S Ayat-Ayat Cinta 2," Indones. Lang. Educ. Lit., vol. 2, no. 2, p. 106, 2017.

[6] S. I. Persulessy, - Emzir, and - AcengRahmat, "Social Values in Charles Dickens's Novel 'Oliver Twist,"” Adv. Lang. Lit. Stud., vol. 9, no. 5, p. 136, 2018.

[7] N. Ifansyah and K. Saddhono, "Lawas : An oral literature in Sumbawa East Indonesia ( East Indonesia ) as a character development means," vol. 2017, no. October, pp. 21-22, 2017.

[8] R. A. Kurbanov, E. I. Nikonova, R. A. Gurbanov, N. V. Svechnikova, K. B. Tumarov, and E. M. Marin, "Anthropological methods of formation of university students' spiritual and moral culture," Int. J. Environ. Sci. Educ., vol. 11, no. 18, pp. 11807 $11817,2016$.

[9] Nursolihah and Reiza D. Dienaputra, "Diskriminasi Ras Dalam Novel Sunda Sripanggung Karya Tjaraka: Analisis Dekonstruksi Derrida,” J. Patanjala, vol. Vol 10 No., 2018.

[10] R. Setyorini, "Hard Working Character in Novel Entrok (Karakter Kerja Keras dalam Novel Entrok)," Indones. Lang. Educ. Lit., 2018.

[11] A. Ang, Lintang Lantip. Yogyakarta: Lontar Mediatama, 2016.

[12] D. M. A. Lexy J. Moleong, Metodologi Penelitian Kualitatif (Edisi Revisi). Bandung, 2010.

[13] S. Endraswara, Metodologi Penelitian Sastra. Yogyakarta: CAPS, 2008.

[14] N. K. Ratna, "Antropologi Sastra: Penggunaan Teori dan Metode secara Eklektik dan Metodologi Campuran,” PUSTAKA, 2012.

[15] E. Wahyuningsi, "PERGESERAN NILAI BUDAYA JAWA DALAM NOVEL CANTING KARYA ARSWENDO ATMOWILOTO: SUATU KAJIAN ANTROPOLOGI SASTRA," J. KATA, vol. 2, no. 2, p. 326, 2018.

[16] M. Mas'udi, "KESETARAAN SUAMI DAN ISTRI DALAM KELUARGA (Analisis Kesetaraan Pembagian Kerja dalam Keluarga Madura)," KONSELING Reli. J. Bimbing. Konseling Islam, vol. 7, no. 2, p. 19, 2017.

[17] H. A. K. Gebreen, "Identity Crisis in Cormac McCarthy's All the Pretty Horses," Adv. Lang. Lit. Stud., vol. 7, no. 2, 2016.

[18] "Representation of Social Realities of Latin America in Marquez's Literary Discourse," Adv. Lang. Lit. Stud., vol. 6, no. 1, 2015.

[19] S. Endraswara, "Politik gaya Sengkuni dan estetika Semar kajian antropologi sastra 
terhadap pemilu legislatif," Masyarakat, Kebud. dan Polit., vol. 27, no. 4, p. 184, 2016.

[20] D. N. Inda, J. Jenderal, and A. Yani, "Eksistensi Budaya Dayak dalam Novel Batas Karya Akmal Nasery Basral The Existence of Dayak Culture in The Novel Batas by Akmal Nasery Basral pengetahuan akan budaya adalah novel . Novel merupakan cerita fiksi dalam bentuk," vol. 10, no. 1, pp. 89-108, 2019.

[21] H. Ali Abdullah Al-Momani, "War Memories and the Refusal of Male Dominance in Shakir's 'Oh, Lebanon,"” Adv. Lang. Lit. Stud., vol. 8, no. 1, p. 118, 2017.

[22] "Psychological and Cultural Borderlands in Tayyib Salih's Season of Migration to the North," Adv. Lang. Lit. Stud., vol. 7, no. 1, 2015.

[23] C. I. Sukrawati, "REFLEKSI BUDAYA BALI DALAM CERPEN TOGOG KARYA NYOMAN MANDA," METASASTRA J. Penelit. Sastra, vol. 8, no. 2, p. 249, 2017.

[24] K. Saddhono, "Integrating Culture in Indonesian Language Learning for Foreign Speakers at Indonesian Universities." J. of Lang. and Lit. vol. 6 no.2 pp. 349-353, 2015

[25] K. Saddhono, S. T, Widodo, M. T. Al Makmun, and M. Tozu, "The study of philosophical meaning of batik and kimono motifs to foster collaborative creative industry." Asian Soc. Sci. vol. 10 no. 9 pp 52-61, 2014 